\title{
COASTAL EROSION AND FLOOD SUSCEPTIBILITY IN PARATY, SOUTHEAST BRAZIL
}

\section{EROSIÓN COSTERA Y SUSCEPTIBILIDAD A INUNDACIONES EN PARATY, SURESTE DE BRASIL}

\author{
Sra. Ana Beatriz Pinheiro1, Sr. André Luiz Carvalho da Silva², Sr.Thiago Gonçalves Pereira ${ }^{3}$, \\ Sr. José Antônio Baptista Neto ${ }^{4}$
}

\begin{abstract}
This study aimed to characterize the behavior of the Paraty shoreline, in the south of the state of Rio de Janeiro, and identify the areas which are most susceptible to erosion and flooding. This region is characterized by a presence the Serra do Mar, marked by a succession of small embayments and narrow coastal plains. The methodology consisted of using a UAV (Unmanned Aerial Vehicle) for the production of orthoimage mosaics (2019) and digital surface models (DSM); shoreline mapping between 2005 and 2019; identification of areas susceptible to erosion and flooding; and flood simulation performed on the Simulate Water Level Rise/Flooding package, from Global Mapper software. The results show that the southern sector of Jabaquara Beach, the beaches of Pontal and Terra Nova (in the center of Paraty - Centro) in the sheltered portion of the coast of Paraty, in addition to Cepilho and Fora (in Trindade), showed erosive behavior over the 14 years analyzed. Ranchos Beach (Trindade) and the northern sector of Jabaquara showed stable behavior and the central sector of Jabaquara showed an accretion during the same period. The coast of Jabaquara, the central area of Paraty, and the southwest sector of Trindade were considered the most vulnerable to flooding due to their susceptibility and the high concentration of the urban and tourist infrastructure of the municipality, where the problems caused by erosion and flooding have been frequently reported by residents and visitors.
\end{abstract}

Keywords: Shoreline. Coastal erosion. Flood susceptibility. Paraty. UAV.

\section{RESUMEN}

Este estudio tuvo como objetivo caracterizar el comportamiento del litoral e identificar las áreas de mayor susceptibilidad a la erosión e inundaciones en la costa de Paraty, en el sur del Estado de Río de Janeiro. Esta región se caracteriza por una presencia de la Serra do Mar, marcado por una sucesión de ensenadas y llanuras costeras estrechas. La metodología adoptada consistió en: utilizar el UAV para generar ortofotomosaicos (2019) y Modelos Digitales de Superficie (MDS); cartografía del litoral, entre 2005 y 2019 ; identificación de áreas susceptibles de erosión e inundaciones; y simulación de inundaciones realizada en el programa Simulate Water Level Rise / Flooding, desde el software Global Mapper. Los resultados muestran que el sector sur de la playa de Jabaquara, las playas de Pontal, Terra Nova en el centro de Paraty, en la porción abrigada de la costa estudiada, así como Cepilho y Fora (en Trindade), presentaron un comportamiento erosivo sobre los últimos 14 años. La playa Rancho (Trindade) y el sector norte de Jabaquara mostraron un comportamiento estable y el extremo norte y centro de Jabaquara mostraron una acreción en los últimos 14 años analizados. La costa de Jabaquara, el área central de Paraty y el sector suroeste de Trindade fueron consideradas las más vulnerables a las inundaciones debido a su susceptibilidad y la alta concentración de la infraestructura urbana y turística de la ciudad, que puede generar daños aún mayores durante las inundaciones.

Palabras clave: Línea costera, Erosión costera, Susceptibilidad a inundaciones, Paraty, UAV.

\footnotetext{
${ }^{1}$ Doctoral student in the Graduate Program Dinâmica dos Oceanos e da Terra, Universidade Federal Fluminense, Niterói, Brazil. ${ }^{2}$ Universidade do Estado do Rio de Janeiro, Faculdade de Formação de Professores, Department of Geography, São Gonçalo, Rio de Janeiro, Brazil.

${ }^{3}$ Universidade do Estado do Rio de Janeiro, Department of Geography, Rio de Janeiro, Brazil.

${ }^{4}$ Universidade Federal Fluminense, Department of Geology and Geophysics, Niterói, Brazil.
} 


\section{INTRODUCTION}

Coastal environments are extremely dynamic and continuously receive flows of energy and matter as they are subjected to a variety of natural processes and are also influenced by human activities. The evolution of coastlines around the world, due to both natural and human-induced factors, can vary on different temporal and spatial scales (Stive et al., 2002). The shoreline is the position of the land-water interface at a given time and, due to its dynamic nature, an analysis of its behavior must consider the temporal and spatial scale of investigation (Boak and Turner, 2005). Coastlines are vulnerable to the effects of globalscale climate change, due to rising sea levels and, on a regional scale, changes in the wave regime (storms) and sediment dynamics. The impacts of these changes tend to generate problems related to the occurrence of flooding and coastal erosion. Erosion occurs when there is a deficit of sediment in the environment, caused by the removal of materials without subsequent replacement (Carter, 1988; Davis JR and Fitzgerald, 2004; Bird, 2008). This scenario is worrying, especially when considering the increase in mean sea level (IPCC, 2014) and the number and intensity of the most intense global storms in recent decades (Webster et al., 2005; Holland and Bruyère, 2014). Through analysis of the behavior of sandy coastlines, based on satellite images, among other methods, Luijendijk et al. (2018) point out that among these sandy environments, about $24 \%$ of the world's sandy beaches are suffering erosion at rates above $0.5 \mathrm{~m} /$ year. As sea levels rise, the coast tends to retreat, and the biggest threat to the continued existence of beaches is engineering structures built that limit their ability to migrate (Cooper et al., 2020). Therefore, the management and monitoring of coastal areas has become increasingly necessary to the understanding of coastline behavior and for the proposal of solutions to such problems.

The concept of susceptibility reflects the coastal system's potential to be affected by a disturbance, for example sea-level rise (Klein and Nicholls, 1999). The analysis of coastal vulnerability always starts with the knowledge of the natural system's susceptibility and of its natural capacity to cope with these effects (resilience and resistance) (Klein and Nicholls, 1999). Vulnerability in this work is directly linked to the capacity of a given system, population, or individual to respond to a threat, considering physical, economic, and social aspects. This will depend on the relationship between the degree of exposure to a physical impact and the ability of populations to absorb and recover from the damage caused by that impact (Adger et al., 2004).

The changes in the coast can be analyzed based on several methodologies, such as through images acquired with LIDAR (Sallenger et al., 2001; Revell et al., 2002; Stockdont et al., 2002; Sallenger et al., 2003; Mitasova et al., 2009; Klemas, 2011; Pe'eri and Long, 2011; Vianna and Calliari, 2015; Tak et al., 2020), from aerial photographs, and satellite images (Souza and Luna, 2010; Macedo et al., 2012; Santos and Bonetti, 2018; Silva et al., 2019; Castillo et al., 2020; Moreira et al., 2020; Castro et al., 2021; Novak and Lamour, 2021), among other methods. In recent years, the use of unmanned aerial vehicles (UAVs), popularly known as drones, represents a potential new tool for data acquisition in several areas of geomorphology (Tonkin et al., 2014; Viles, 2016). UAVs provide a solution for high-resolution mapping of small areas and are also a low-cost alternative to classical aerial photogrammetry (Remondino et al., 2011; Gonçalves and Henriques, 2015). This methodology has been useful and accessible for monitoring studies of coastal dynamics, in addition to assisting in the management of these environments (Gonçalves et al., 2010; Gonçalves and Henriques, 2015). In Brazil, studies carried out on the southern coast stand out (Scarelli et al., 2016; Albuquerque et al., 2018; Oliveira and Simões, 2018; Simões et al., 2019; Oliveira et al., 2020; Simões and Oliveira, 2020). There are many advantages to using this tool, especially the high-precision data acquisition at a low operating cost; the high level of automation; photograph visualization during field work, enabling repetition in the case of failure; and fast flight planning (Gonçalves and Henriques, 2015).

Studies aimed at understanding the dynamics and behavior of the coast of Paraty are scarce. The occurrence of impacts arising from storm events, such as frequent flooding, damage to structures, and erosion in certain places are records of the susceptibility of the Paraty coast to storm waves (Pinheiro et al., 2021). Studies on erosion and flooding susceptibility are fundamental for the knowledge of the several variables related to the dynamics and behavior of the coastline, which can help in decision-making and in the adoption of measures related to local coastal management. In this sense, the present study aimed to characterize the behavior of the shoreline and the susceptibility to erosion and flooding on the Paraty coast, in the south of the state of Rio de Janeiro (Figure 1). 


\section{STUDY AREA}

The municipality of Paraty (Figure 1) was the seat of the most important gold exporting port in Brazil in the 18th century. In 2019, it was recognized as cultural and natural heritage of humanity by the United Nations Educational, Scientific, and Cultural Organization (UNESCO). Tourism is the main economic activity of the city, which attracts many visitors from various parts of Brazil and the world, due to the great cultural festivals and the beautiful beaches, islands, waterfalls, and trails surrounded by Atlantic Forest (Benchimol, 2007; Padilha, 2016). Despite this rich biodiversity and geodiversity, the studies carried out on this part of the Rio de Janeiro coast are still not very representative when compared to other areas in the state of Rio de Janeiro.

The Paraty coast exhibits a diversity of environments, such as coastal plains, beaches, rocky shores, slopes, and mangrove areas, in addition to a large number of conservation units to protect these environments (Figure 2). Its rocky coast is dominated by mountains (Serra do Mar) (Figure 2), composed of granites and gneisses (Faria, 2018). This region, known as Costa Verde, or Green Coast, is characterized by a coast with numerous islands and a jagged coastline, with a succession of small inlets and narrow coastal plains (Muehe, 2001; Medeiros, 2006; Muehe, 2018). The coastal plain appears discontinuously in the study area. Beach ridges are common on the sandy plain and appear parallel to the shoreline, with a north-south orientation (Figure 2) and represent former positions of the shoreline (Otvos, 2000, Davis JR. and Fitzgerald, 2004; Tamura, 2012). There are also many pocket beaches on this coast, which are characterized by the reduced extension of the sand strip and are separated by crystalline basement headlands (Muehe, 2001). The mangroves are located in the interior of the bay, in areas with lower hydrodynamics (Figure 2).

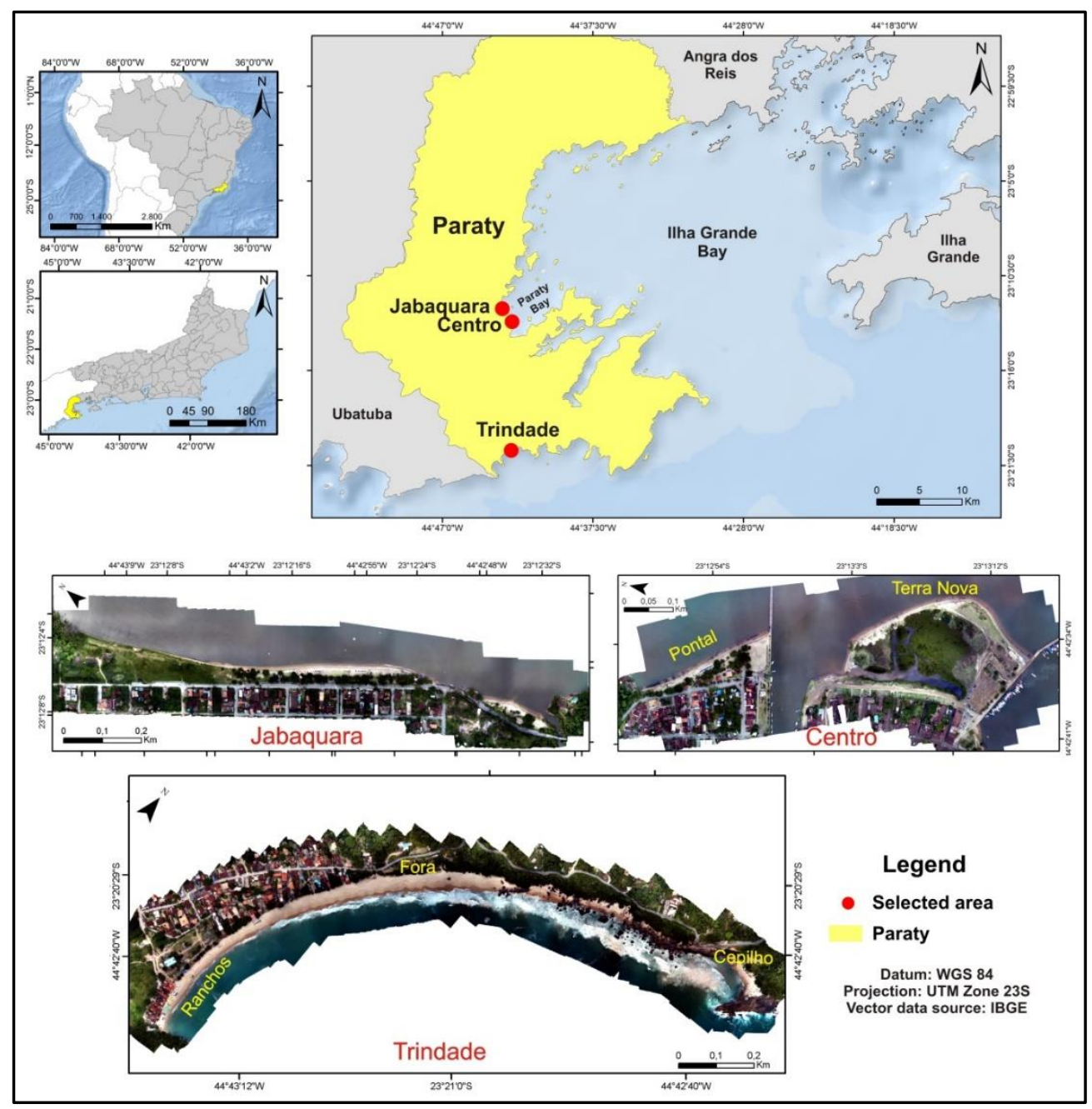

Figure 1. Location map of the studied areas. Self-elaborated. 


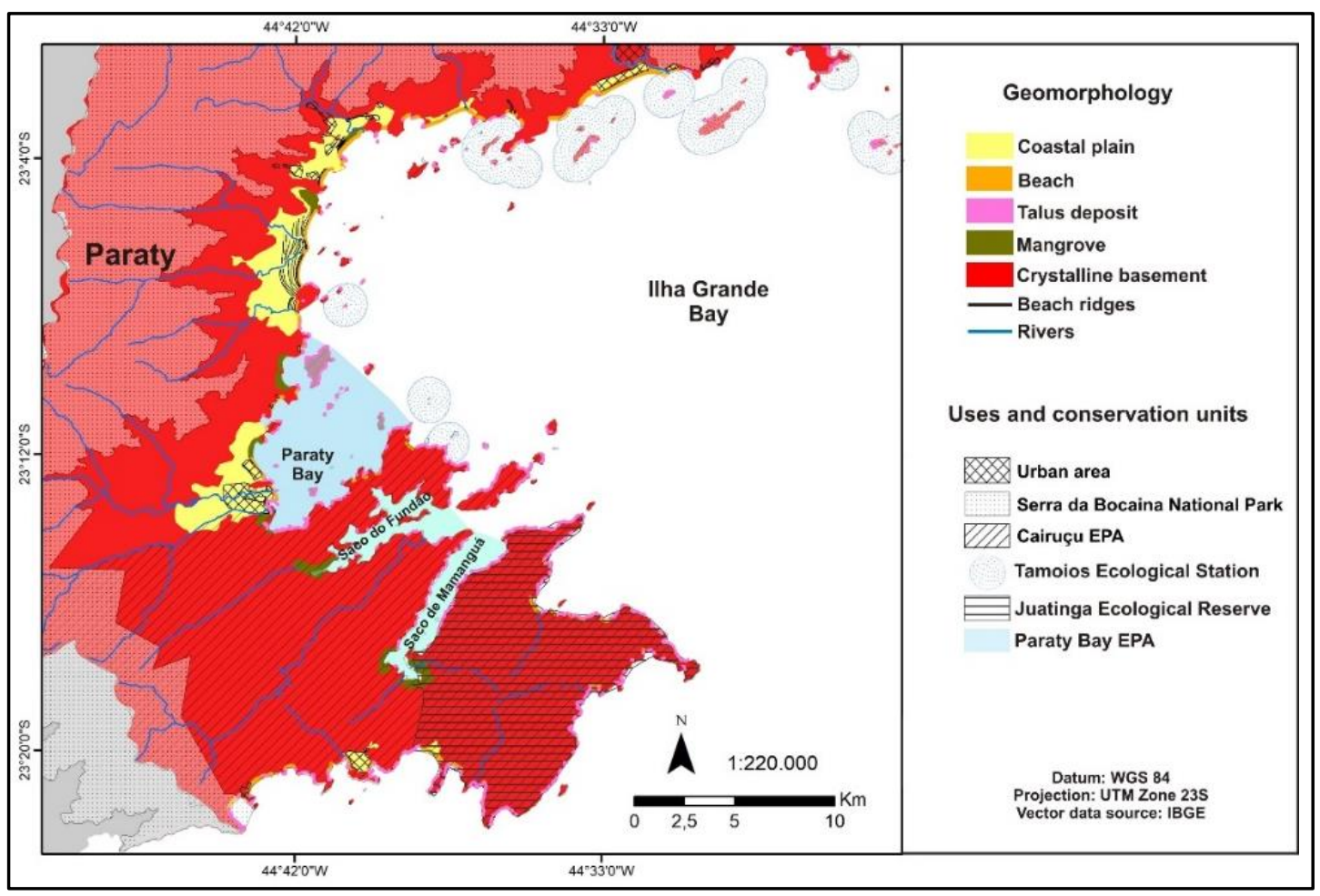

Figure 2. Geomorphological map and conservation units on the coast of Paraty. PARNA - National Park; EPA Environmental Protection Area; ESEC - Ecological Station; JER - Juatinga Ecological Reserve. Self elaborated.

In the state of Rio de Janeiro, the tide does not exceed 1.5 meters (DHN, 1980) and the waves are, therefore, the main process responsible for the dynamics of this coast. The beaches located in the extreme south of Paraty are directly exposed to the direct incidence of waves, while those located in the western sector of llha Grande Bay are partially sheltered in relation to wave dynamics. The waves arriving at Ilha Grande Bay can be intercepted due to the bay's geomorphology, and those from the south and southeast are easier to enter, which makes llha Grande Bay sensitive to storms in the southeast and tend to reach normally protected regions, potentially causing impacts on the coastal structures, especially when they occur associated with the spring tide (Godoi et al., 2011).

The southern coast of Rio de Janeiro has small rivers and channels that bring sediment from the slopes and deposit it on the beaches (Carvalho et al., 2011; Silva et al., 2020; Pinheiro et al., 2021). These rivers and channels are fed by a regime of tropical rains, concentrated in the summer months, with annual rainfall exceeding 2,000 mm (Salgado et al., 2007). The sedimentation in Ilha Grande Bay is mainly composed of very fine sand in the western portion and adjacent continental shelf, medium to coarse sand in the eastern portion, and silt in the central channel and sheltered areas (Mahiques, 1987). The transport of sediments from the inner continental shelf towards the beaches in the interior of the bay is influenced by the presence of the island of liha Grande, which acts as a barrier to these sediments reaching the continent and also to wave propagation, with greater energy going to the interior of the bay due to the configuration of this coastline (Muehe et al., 2006; Muehe, 2018).

For this study, three areas with distinct geographic and geomorphological characteristics were chosen (Figure 1). Jabaquara and the center of Paraty (Centro) are located in the interior of llha Grande Bay and, therefore, are partially sheltered in relation to the direct incidence of waves. The beaches of Paraty have distinct morphological and sedimentary dynamics in response to different levels of exposure to storm events, which depend on the direction of wave incidence, the location of the beaches in relation to the opening of the bay and the presence of islands (Andrade, 2012; Pinheiro, 2021). Despite being sheltered, these beaches have been affected by storm waves that damage urban structures (Pinheiro et al., 2021) and present problems due to recurrent flooding during the spring tide (Benchimol, 2007). On the other hand, the beaches located in Vila de Trindade comprise the oceanic part of this coast, exposed to the direct incidence of waves. All the 
studied areas have some type of urban infrastructure, such as kiosks, restaurants, residences, and bicycle paths, among others, almost always very close to or even within the limits of the beach.

\section{METHODOLOGY}

Three areas were selected to characterize the behavior of the shoreline over a period of 14 years and for the identification of sites susceptible to erosion and flooding on the coast of Paraty. Two of the chosen sectors are located in the sheltered part of the studied coast (Jabaquara and the Centro) and the other is located in the area facing the ocean (Trindade).

For shoreline mapping, the methodology used was based on orthophotos from the IBGE (2005) database; satellite images $(2008,2011,2016$, and 2017) made available on Google Earth Pro and properly georeferenced from the IBGE orthophotos; and orthomosaics acquired using UAV (2019). These were initially vectored and later plotted on the 2019 orthophotomosaic for shoreline comparison. A total of 27 support points obtained by geodetic tracking were distributed along the areas mapped with the UAV, to ensure the precision in the coordinates and accuracy of the generated products.

In the present study, the wet/dry contact of the beach sand was chosen as an indicator of the position of the shoreline (Boak and Turner, 2005). Shoreline behavior analysis was performed based on the classification proposed by Luijendijk et al. (2018) for sandy beaches, which establishes the following categories: accretion ( $>0.5 \mathrm{~m} / \mathrm{year}$ ); stable ( -0.5 to $0.5 \mathrm{~m} /$ year); erosion ( -1 to -0.5 $\mathrm{m} /$ year); intense erosion ( -3 to $-1 \mathrm{~m} /$ year); severe erosion ( -5 to $-3 \mathrm{~m} /$ year); and extreme erosion (< $-5 \mathrm{~m} /$ year). For this, the interval between the oldest and the most recent shoreline was calculated and divided by the period of time analyzed, thereby generating an average of the annual movement of the shoreline (m/year). Geoindicators, adapted from Bush et al. (1999), were also used to indicate areas susceptible to coastal erosion. Geoindicators have their applications aimed at coastal management, where risk/hazard assessment and damage mitigation are the main concern (Bush et al., 1999). This methodology is used to assess predisposition factors to coastal erosion, based on evaluation parameters such as: degree of exposure to storm events, vegetation characteristics, site elevation, absence of dunes, wave transposition, engineering structures and the beach characteristics. Geoindicators are organized into seven categories and classified into three levels of susceptibility (low, medium, and high). Values (Table 1) and classes for susceptibility mapping were assigned to each category: low (7 to 11), medium (12 to 16), and high (17 to 21$)$.

\begin{tabular}{|c|c|c|c|}
\hline \multirow{2}{*}{ Geoindicator } & \multicolumn{3}{|c|}{ Susceptibility Category } \\
\hline & High (Weight 3) & Medium (Weight 2) & Low (Weight 1) \\
\hline $\begin{array}{l}\text { 1. Degree of } \\
\text { exposure }\end{array}$ & Exposed & Semi-exposed & Protected \\
\hline 2. Vegetation & $\begin{array}{l}\text { Sterile, scarce, fallen } \\
\text { trees }\end{array}$ & $\begin{array}{l}\text { Well-established shrubs } \\
\text { and grasses; no fallen } \\
\text { trees }\end{array}$ & $\begin{array}{l}\text { Well-developed vegetation; no } \\
\text { evidence of erosion on vegetation }\end{array}$ \\
\hline 3. Elevation & $<3 \mathrm{~m}$ & $3-6 m$ & $>6 \mathrm{~m}$ \\
\hline 4. Dunes & $\begin{array}{l}\text { Absent or artificially } \\
\text { removed }\end{array}$ & $\begin{array}{l}\text { Low or discontinuous } \\
\text { dunes; destroyed dunes }\end{array}$ & Tall and vegetated dunes \\
\hline 5. Overwash & Frequent & Occasional & Absent \\
\hline $\begin{array}{l}\text { 6. Engineering } \\
\text { structures }\end{array}$ & $\begin{array}{l}\text { Numerous structures } \\
\text { (walls, breakwater) }\end{array}$ & $\begin{array}{l}\text { Few structures close to } \\
\text { the beach }\end{array}$ & Absent \\
\hline 7. Beach Features & $\begin{array}{l}\text { Narrow and steep; poor } \\
\text { supply of sand }\end{array}$ & $\begin{array}{l}\text { Moderate to narrow } \\
\text { width; potential for } \\
\text { disruption of sand supply }\end{array}$ & $\begin{array}{l}\text { Wide and flat; with a well- } \\
\text { developed berm; good supply of } \\
\text { sand }\end{array}$ \\
\hline
\end{tabular}

Table 1. Geoindicators of susceptibility to coastal erosion. Source: Bush et al. (1999).

To identify areas susceptible to flooding, photographs of extreme events that occurred between August and October 2016 were used. The coordinates of locations with recurrent floods were represented on Google Earth Pro and DSM, to correlate with the corresponding altimetric level. The flooded altitude was inserted in the Simulate Water Level Rise/Flooding package of the Global Mapper V.22 software, to reconstitute 
the event and identify the most susceptible areas, as per Vianna et al. (2020). This tool enables the simulation of flooded areas, based on the knowledge of the increase in mean sea level or the maximum altitude flooded during a given event (Vianna et al., 2020). From the simulation, the flooded area was vectored on ArcGis 10.7 and placed on the orthomosaic corresponding to the year 2019, for better identification of places susceptible to flooding.

The 2019 orthomosaics and digital surface models (DSM) were obtained from a UAV, a DJI Phantom 4 Advanced model, equipped with a 20 megapixels camera with a focal length of $24 \mathrm{~mm}$. The flights were carried out in ideal weather conditions, with wind speeds below $5 \mathrm{~m} / \mathrm{s}$, at an altitude of between 102 and $110 \mathrm{~m}$, in the three areas selected for this study (Table 2). As such, flight plans were previously made and executed on MAPPILOT software. The size of the area of interest, the degree of vegetation cover, the flight height, and the representation of the pixel of the image on the ground (Ground Sample Distance) and the distribution of support points (Table 2) were analyzed. The support points were distributed across the flyover area and georeferenced with a DGPS (Differential Global Positioning System) model GTR-G2 by TechGeo to ensure precision in the coordinates and accuracy of the generated products. The aerial photographs were processed on Agisoft Photoscan Professional software, using structure from motion techniques (Cook, 2017) on the images obtained, with the aim of generating the final cartographic products.

\begin{tabular}{llllllll}
\hline Local & Date and time & $\begin{array}{l}\text { Altitude } \\
(\mathrm{m})\end{array}$ & $\begin{array}{l}\text { Area } \\
\left(\mathrm{km}^{2}\right)\end{array}$ & $\begin{array}{l}\text { Images } \\
\text { obtained }\end{array}$ & $\begin{array}{l}\text { Support } \\
\text { points }\end{array}$ & $\begin{array}{l}\text { Soil sample } \\
\text { distance - GSD } \\
(\mathrm{cm} / \mathrm{pix})\end{array}$ & $\begin{array}{l}\text { Root mean } \\
\text { square error } \\
\text {-RMS (pix) }\end{array}$ \\
\hline Jabaquara & $12 / 09 / 191$ p.m. & 110 & 0.36 & 285 & 9 & 2.7 & 0.38 \\
Centro & $12 / 10 / 1910$ a.m. & 102 & 0.17 & 219 & 8 & 2.6 & 0.37 \\
Trindade & $12 / 10 / 192$ p.m. & 109 & 0.18 & 379 & 10 & 2.9 & 0.69 \\
\hline
\end{tabular}

Table 2 - Data obtained with the UAV. Self elaborated.

\section{RESULTS AND DISCUSSION}

\section{Erosion susceptibility and shoreline behavior over 14 years}

\section{Paraty's sheltered shoreline (Jabaquara and Central Area)}

The Jabaquara Beach arc (Figure 3) is 1,230 meters long, of NW-SE orientation, and is limited by the mangrove vegetation to the northwest and by the narrow channel of the Perequê-Açu River at the southeastern limit. It is the biggest and most important beach in the central area of the city of Paraty. It has many inns and restaurants along the shore and receives a large number of visitors. The waves arriving at the beach are low energy, with heights of less than $40 \mathrm{~cm}$ under good weather conditions and not exceeding 1 meter during storm conditions (Pinheiro et al., 2021). The shoreline of the Jabaquara Beach arc showed significant changes over the observed time series (Figure $3 \mathrm{~A}$ ). In the northern sector of Jabaquara, the shoreline advanced $8 \mathrm{~m}$ towards the sea between 2005 and 2016. However, in the period between 2016 and 2019, it can be noted that it retreated about $6 \mathrm{~m}$ towards the mainland, to a position very similar to the position mapped for the year 2005 (Figure 3B). Moments of advance and retreat are part of the natural dynamics of this environment. In the analyzed period (14 years), the shoreline in this sector showed stable behavior, with a rate of change of $0.2 \mathrm{~m} /$ year. Between 2005 and 2019, the center of the Jabaquara Beach arc presented an advance of about $17 \mathrm{~m}$ towards the sea, (Figure 3C) which indicates accretion behavior of the shoreline over the 14 year period, with a variation rate of $1.2 \mathrm{~m} /$ year. The southern sector of Jabaquara (Figure 3D) presented an advance of about $5 \mathrm{~m}$ towards the sea between 2005 and 2011. However, between 2011 and 2016 there was a retreat of approximately $13 \mathrm{~m}$, followed by a rapid advance of $8.5 \mathrm{~m}$ between 2016 to 2017 , when the shoreline presents a position similar to that observed in 2005. A strong retrogradation of the shoreline, of about $12 \mathrm{~m}$, marks the period between 2017 and 2019. When analyzing the behavior of the shoreline for the entire period of 14 years (2005 to 2019), there was a predominance of a retreat in towards the continent of approximately $11 \mathrm{~m}$, despite the observed variability (Figure 3D), indicating erosive behavior, with a variation rate of -0.7 $\mathrm{m} /$ year. The extreme south of Jabaquara was the stretch that presented the most accentuated 
retreat (Figure 3E). Between 2005 and 2011, this sector showed a retreat of $6 \mathrm{~m}$ towards the continent, and between 2011 and 2016, there was a significant reduction of about $14 \mathrm{~m}$, without further recovery (Figure 3E). When comparing the initial (2005) and final (2019) positions of the shoreline, a total retreat of around $32 \mathrm{~m}$ towards the continent can be observed (Figure 3E), which is the result of intense erosive behavior, with a rate of change of $-2.2 \mathrm{~m} /$ year.

Based on the observed geoindicators, Jabaquara Beach exhibits a susceptibility to erosion ranging from medium to high (Figure $3 \mathrm{~A}$ ), which corroborates the data presented here in relation to the behavior of the shoreline. The northern sector does not have frontal dunes, has low elevation and a narrow profile. However, the medium susceptibility of this sector to erosion is due to the absence of constructions on the beach boundary and its greater protection from the incidence of waves (Figure 3A). The southern sector was classified as highly susceptible to erosion (Figure $3 \mathrm{~A}$ ). It is the most worrying sector, as it is a low-elevation area with a narrow profile; shows evidence of erosion on the vegetation, such as root exposure and fallen trees (Figure 4A and $B$ ); has numerous buildings located on the sand strip;retreat of the shoreline; and there is evidence of wave transposition during storm events, causing recurrent flooding in the streets near the beach (Figure $4 \mathrm{C}$ and $\mathrm{F}$ ).

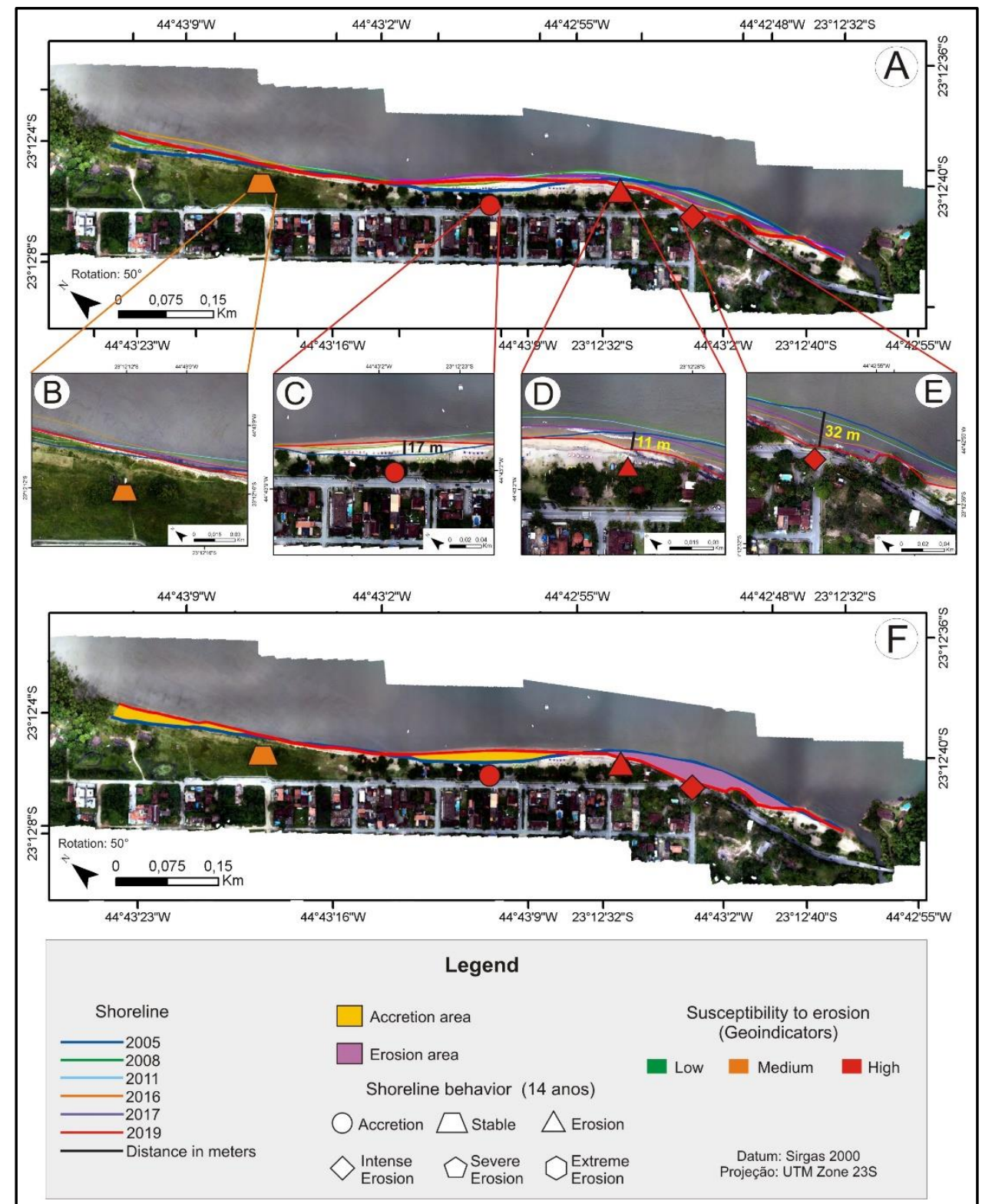

Figure 3. Shoreline variation map and erosion susceptibility on Jabaquara Beach. The purple color indicates the eroded area and the yellow color indicates the added area. Self elaborated. 


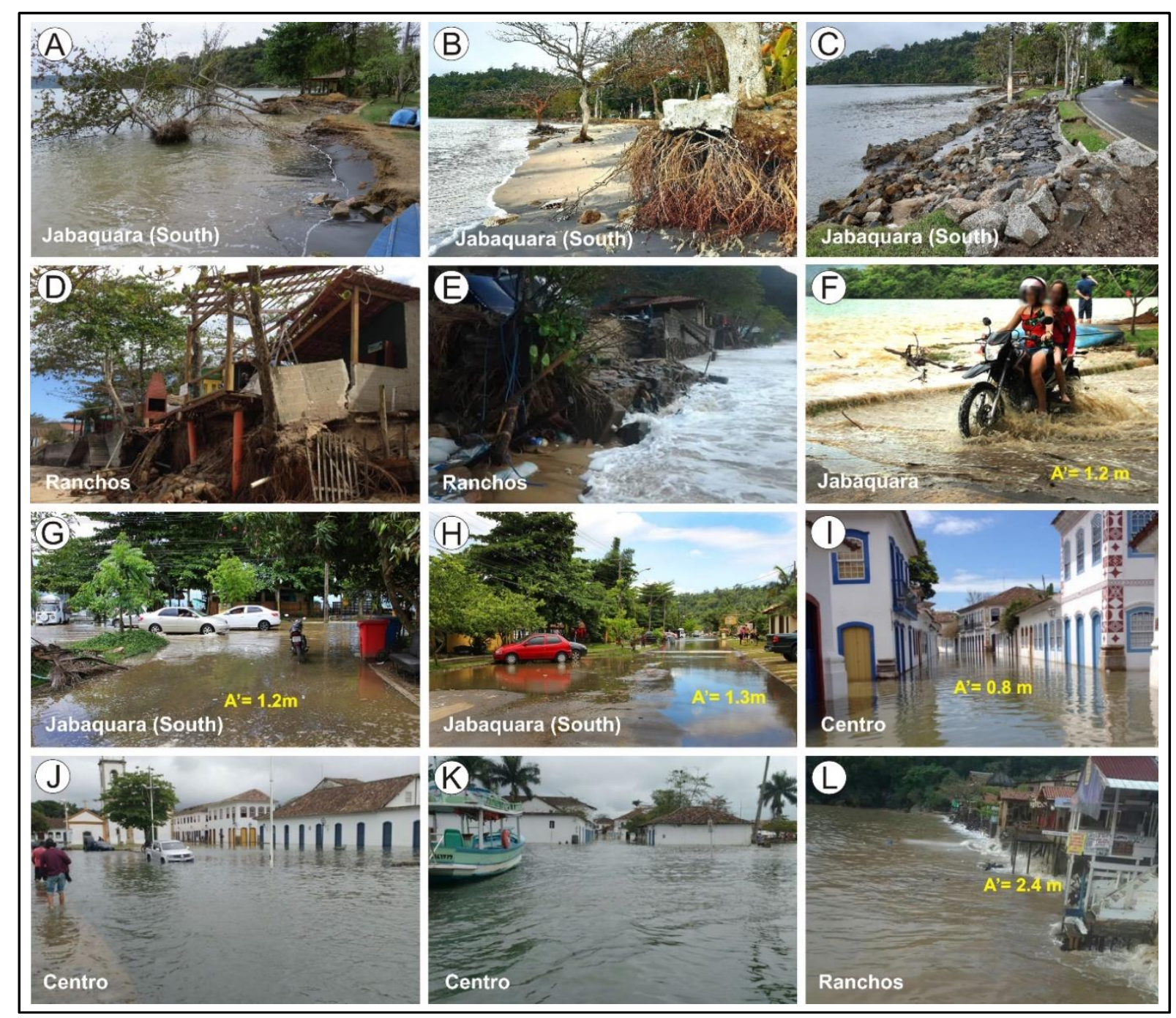

Figure 4. Floods and damage caused by the extreme events of 2016. Photos: A - André Silva, 2016; B and C - André Silva, 2019; D, E and L - Trindade Residents Association (AMOT), 2016; F, G, H and I - Nelson Costa, 2016; J and K - www.g1.globo.com. The Letter A' - Corresponds to the altitude (in relation to sea level) of the places flooded during the extreme events that occurred in 2016.

Pinheiro et al. (2021), based on topographic profiles and analysis of the beach sediment volume between 2016 and 2018, showed that the northern sector of Jabaquara presented slight changes, with sediment gain in the summer $(22 \%)$, followed by smaller losses in winter (18\%), showing very similar profiles between seasons, which points to the same stability observed in this study. The southern sector of Jabaquara Beach is the most worrying. Urban structures and trees that were once outside the beach boundary, due to the retreat of the shoreline, are being hit and knocked down by wave action (Figure 4A, B and C). In this sector, the beach showed a marked reduction of $70 \%$ in the sediment volume over two years $(2016$ to 2018 ) and a $7 \mathrm{~m}$ retreat from the storm scarp, showing a marked retreat of the shoreline (Pinheiro et al., 2021). To minimize the impact of storm waves on this stretch, the city built a retaining wall in 2018 , which was later destroyed by these waves. The erosive process was accentuated by successive storm events that occurred in 2016, especially that of October 2016 , when a strong extratropical cyclone hit the southeast and south coasts of Brazil (CPTEC/INPE, 2016). This event was considered one of the largest recorded in the last 40 years on the coast of Rio Grande do Sul (Oliveira et al., 2019).

Since then, further evidence of erosion has been observed in this sector of Jabaquara Beach, as per the criteria of Bird (2008) and Souza (2009), these being fallen trees (Figure 4A), root exposure (Figure 4B), the destruction of structures built on the back beach (Figure 4C), a 
high concentration of heavy minerals in the narrow backshore (Figure $4 \mathrm{~A}$ and $\mathrm{B}$ ), and flooding during the most intense events (Figure 4F to $\mathrm{H}$ ). During the studied period of 14 years, this coastal sector lost approximately $5,927 \mathrm{~m}^{2}$ of beach area (Figure 3F). Much of the eroded sediments in the southern sector of this beach arc may have been transported through currents towards the northwest (center and north end of the beach arc) (Figure 3F), where there was a gain of around $6,010 \mathrm{~m}^{2}$ of beach area. Tidal currents can be an important process in restricted environments such as estuaries and bays (Nordstrom, 1989; VilaConcejo et al., 2020). In these areas, tidal currents can contribute to the erosion and deposition process, through the redistribution of sediments along the coast, in addition to exporting sediments to depths where they can no longer be remobilized by low energy waves (Vila-Concejo et al., 2020).

The central area of Paraty, close to the Historic Center, is one of the most urbanized places and, consequently, the most modified in the city. North of the Perequê-Açu river, at Pontal Beach, the position of the shoreline changed significantly over the 14 years from 2005 to 2019, especially in the vicinity of the rock jetty (Figure 5), where there was a retreat towards the continent of approximately $35 \mathrm{~m}$ (Figure 5), despite being a sector subject to low dynamics. This scenario points to intense erosion behavior, with a rate of change of $-2.5 \mathrm{~m} /$ year. To the south of the Perequê-Açu river, in the area called Terra Nova, there were changes in the position of the shoreline, especially in the northern sector, which presented a retreat of about 49 m between 2005 and 2019 (Figure 5), indicative of severe erosion, with a rate of change of $-3.5 \mathrm{~m} /$ year. The southern sector, close to the pier, showed a retreat of approximately $18 \mathrm{~m}$ over the same period, showing intense erosive behavior, with a rate of change of $-1.3 \mathrm{~m} / \mathrm{year}$. The center of Paraty was classified as an area of high susceptibility to erosion, based on geoindicators (Figure 5), being an area with numerous constructions near the beach that is flooding during storm events, and has a narrow beach profile and low elevation in relation to sea level.

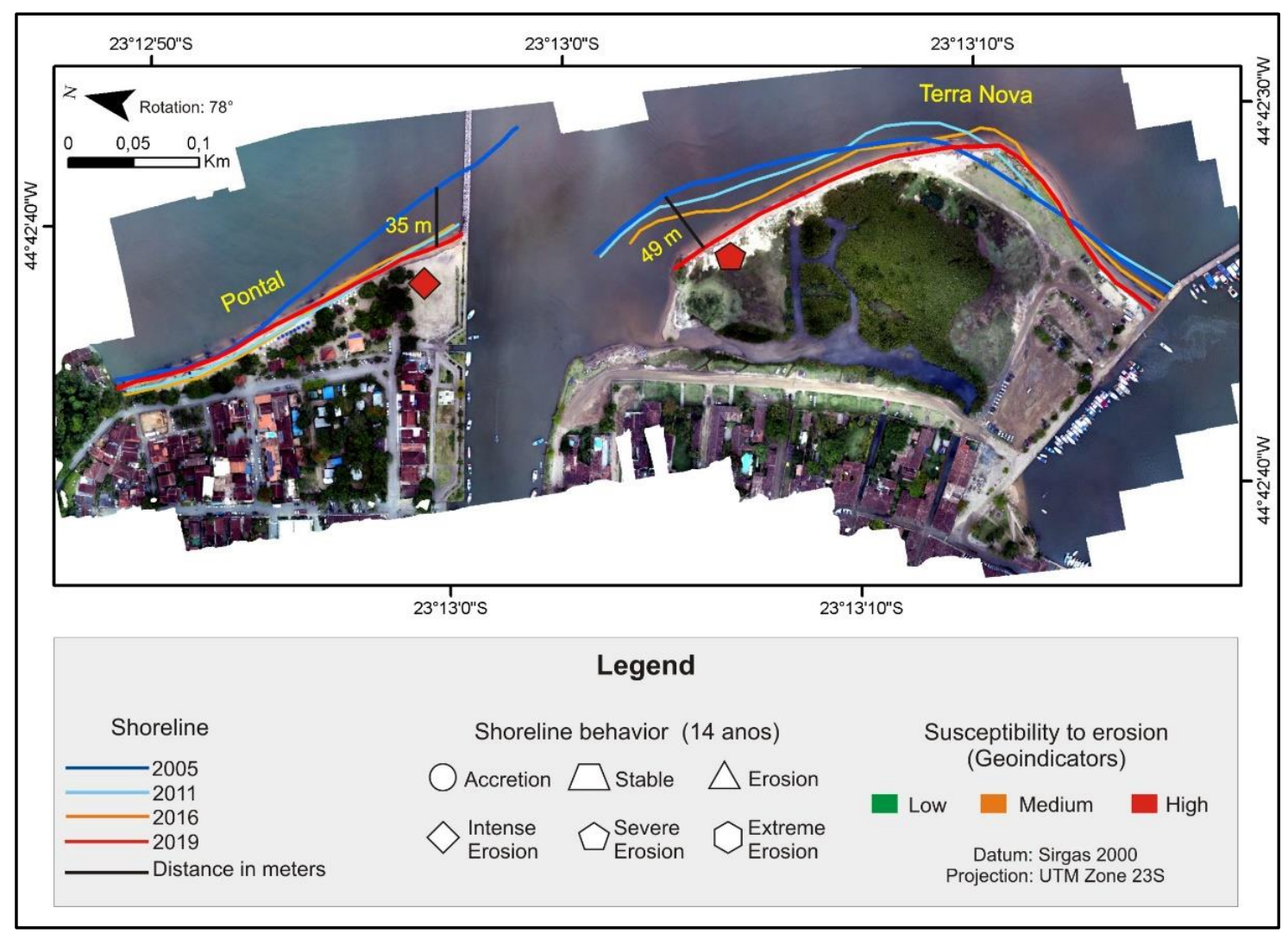

Figure 5. Shoreline variation map in the Center of Paraty area. Self elaborated.

The central areas of Paraty (Jabaquara and Centro) underwent repeated modifications throughout the process of urban expansion (Benchimol, 2007; Villena et al., 2013), which may 
have modified the local hydrodynamics, interrupting the transport of sediments from the river to the coast and contributing to the erosion process. Changes in the courses of the city's rivers and the construction of a jetty between the 1970 s and 1980s on the margins of the PerequêAçu river, meant that Pontal Beach, which previously received an expressive sedimentary contribution (Benchimol, 2007), began to experience severe erosion problems. As a result, an accumulation of sediments began on the opposite margin, in front of the Historic Center, in the area called Terra Nova (Benchimol, 2007). The construction of rigid structures such as jetties or breakwaters can interrupt the exchange of sediments along the coast for the longshore current, causing an accumulation of sand on one side of the structure and, at the same time, a deficit on the opposite side (Davis JR and Fitzgerald, 2004; Bird, 2008). Several studies have shown the negative effects of the introduction of rigid structures on beaches, which generally result in changes in sedimentary dynamics, as observed in Barra do Furado (Rio de Janeiro) by Dias and Kjerfve (2009); on beaches in Greece and Cyprus (Tsoukala et al., 2015); on the coast of Africa (Boer et al., 2019); and on the beach of Cieneguita (Costa Rica) by Castillo et al. (2021). In addition, the sheltered beaches have characteristics that may also have contributed to this process, such as the low exchange of sediments with adjacent beaches, slow post-storm recovery and the low energy of prevailing waves (Nordstrom, 1989; Jackson et al., 2002). The erosive process, especially on Jabaquara Beach, was accentuated by successive storm events that occurred in 2016, as also verified by Pinheiro et al. (2021). This is even more worrying when considering the increase in the number and intensity of the most intense storms around the world in recent decades (Webster et al., 2005; Holland and Bruyère, 2013). Even with new interventions carried out by the city in order to contain the problem of erosion on Pontal Beach (Benchimol, 2007), it was possible to note with this study that the erosion process continues and seems to extend to Terra Nova (Figure 5).

\section{PARATY OCEAN SECTOR (TRINDADE)}

The coast of Vila de Trindade has a NE-SW orientation and is limited by rocky shores (Figure $6 \mathrm{~A})$. Cepilho Beach, in the northeastern sector, is a pocket beach, approximately $340 \mathrm{~m}$ long, separated from the others by outcrops of the crystalline basement. Fora Beach and Ranchos Beach (Figure 6A) are located towards the southwest (in the central area of the village) in a $1.5 \mathrm{~km}$ long beach arc. Between 2005 and 2017, Ranchos Beach presented an advance towards the sea of about $12 \mathrm{~m}$. However, in just two years, from 2017 to 2019, there was a retreat of $9 \mathrm{~m}$, to a position similar to the initial position (year 2005) (Figure 6B). This indicates stable behavior for this beach sector in the period analyzed, with a rate of change of $0.3 \mathrm{~m} /$ year. However, this coastal sector is commonly hit by large storm waves, which have caused damage to buildings located close or inside to the beach, in addition to felling trees and flooding, as occurred in August 2016. Between 2005 and 2019, Fora Beach (middle of the beach arc) showed a retreat towards the continent of about $32 \mathrm{~m}$ (Figure 6C), which suggests intense erosive behavior of the shoreline, with a rate of change of $-2.2 \mathrm{~m} / \mathrm{year}$. At Cepilho Beach, from 2005 to 2019, there was a retreat towards the continent of $35 \mathrm{~m}$, being more intense in the period between 2017 and 2019 (22 $m-$ Figure 6D). Such changes point to an intense erosion process, with a rate of change of -2.5 $\mathrm{m} /$ year. The geoindicators showed a susceptibility to erosion ranging from high (Ranchos) to medium (other beaches) (Figure 6A). Fora Beach and Cepilho Beach are in locations exposed to direct waves, with no frontal dunes, elevation of less than $3 \mathrm{~m}$, and moderate to narrow width of the beach profile. However, the low presence of constructions at the back beach and the absence of evidence of erosion on the vegetation, points to a medium susceptibility of these beaches to erosion (Figure 6A). Ranchos Beach is the most worrying, as it has numerous constructions close or inside to the beach and because of its history of destruction and flooding (Figure 4D and E) during storms, which makes this stretch of the beach arc more susceptible to erosion.

The comparison between the results obtained in this study with those of Luijendijk et al. (2018), for the Trindade region, enables the observation of certain divergences. In this study, Fora Beach showed erosive behavior with a rate of change of -2.2 m/year, being classified as intense erosive behavior during the analyzed period of 14 years (Figure 6). Luijendijk et al. (2018), on the other hand, suggest a rate of change of $0.1 \mathrm{~m} / \mathrm{year}$, classifying Fora Beach as stable during a 32-year period (1984-2016). Based on the data presented here, Ranchos Beach showed stable behavior over the last 14 years, with a rate of change of 0.3 $\mathrm{m} /$ year (Figure 6), corroborating the results presented by Luijendijk et al. (2018), which indicate stability over a 32-year period, with a rate of change of $0.1 \mathrm{~m} /$ year, for the same location. 


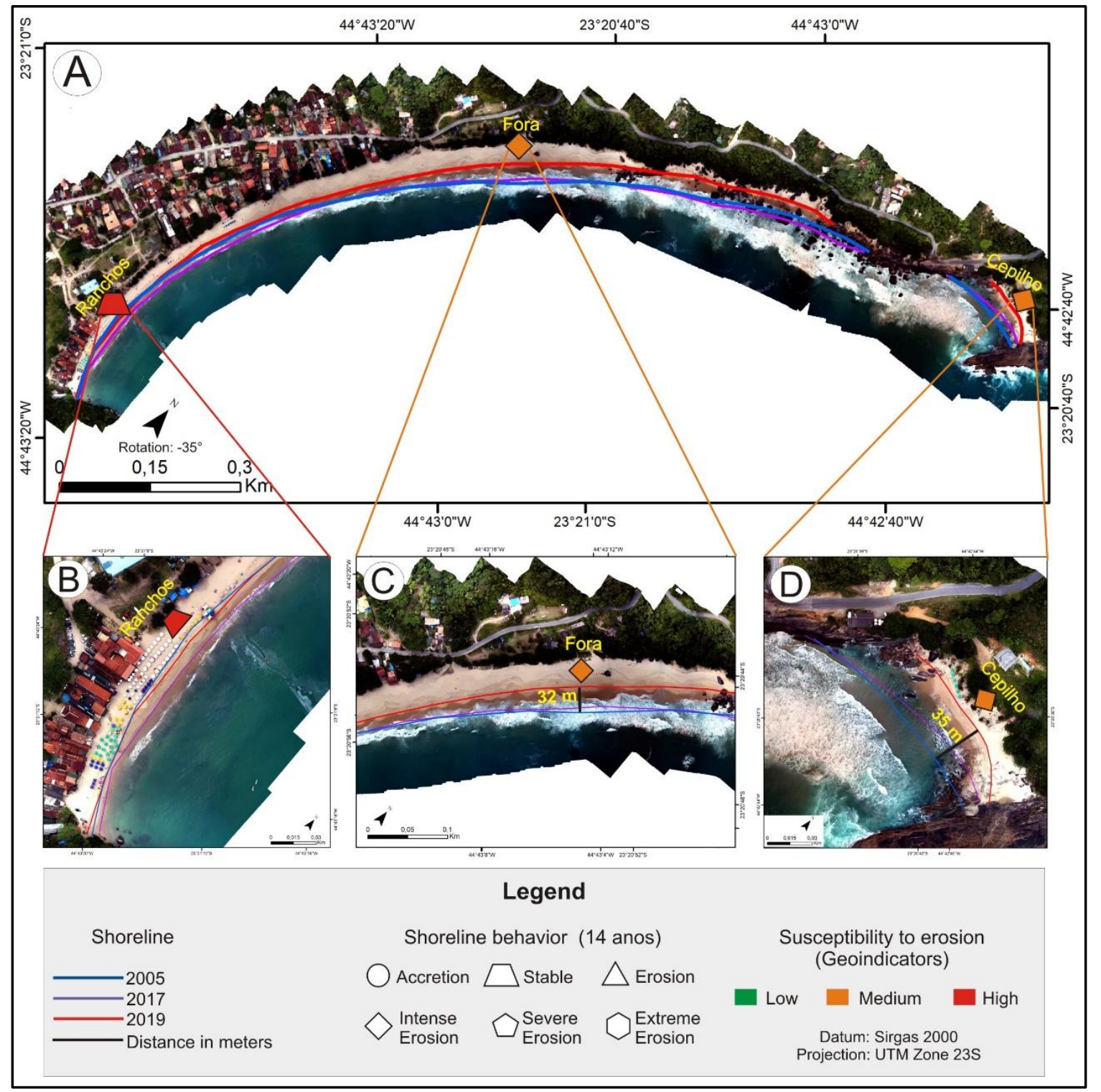

Figure 6. Shoreline variation map and erosion susceptibility in the Trindade area. Self elaborated.

\section{SUSCEPTIBILITY TO FLOODING}

From the Digital Surface Model (DSM) and historical images, it was possible to identify areas of greater susceptibility to flooding. Jabaquara Beach and the central area of Paraty (Figure 7A and $B$ ) were the places with the lowest altitude in relation to mean sea level. The DSM of Jabaquara Beach shows a shoreline with a low topography, with an average altimetry around $1.2 \mathrm{~m}$ in relation to mean sea level, with the exception of the rocky areas to the south, which reach $20 \mathrm{~m}$ (Figure 7A). The city center region was the area with the lowest topography, which is predominantly flat, with an altimetry between 0.5 and $1 \mathrm{~m}$ in relation to mean sea level, reaching $30 \mathrm{~m}$ only at the crystalline basement (Figure 7B). The DSM in Trindade showed a higher topography compared to the other areas, with an altitude between 2 and to mean sea level, reaching $41 \mathrm{~m}$ in the areas over the crystalline basement (Figure 7C). $3 \mathrm{~m}$ in relation

The knowledge of the maximum altitude flooded during an extreme event (according to each mapped area), when superimposed on the digital surface model, enables the identification of areas potentially susceptible to flooding, based on simulations (Vianna et al, 2020). The areas identified here as more susceptible to flood events (Jabaquara and Centro, with emphasis on Terra Nova) are frequently flooded during periods of 
high syzygy, combined with storm waves. A momentary rise of about $8 \mathrm{~cm}$ from mean sea level can cause frequent flooding in these topographically lower areas (Figure $8 \mathrm{~A}$ and $\mathrm{B}$ ). On Jabaquara Beach, during the extreme events that occurred between August and October 2016, the flooded altitude was about $1.3 \mathrm{~m}$ in relation to mean sea level (Figure 4H). At that time, approximately $43,289 \mathrm{~m}^{2}$ of area was flooded (Figure $8 \mathrm{~A}$ ), causing damage to the entire edge and to some streets parallel to the beach (Figure $4 \mathrm{~F}$ to $\mathrm{H})$.

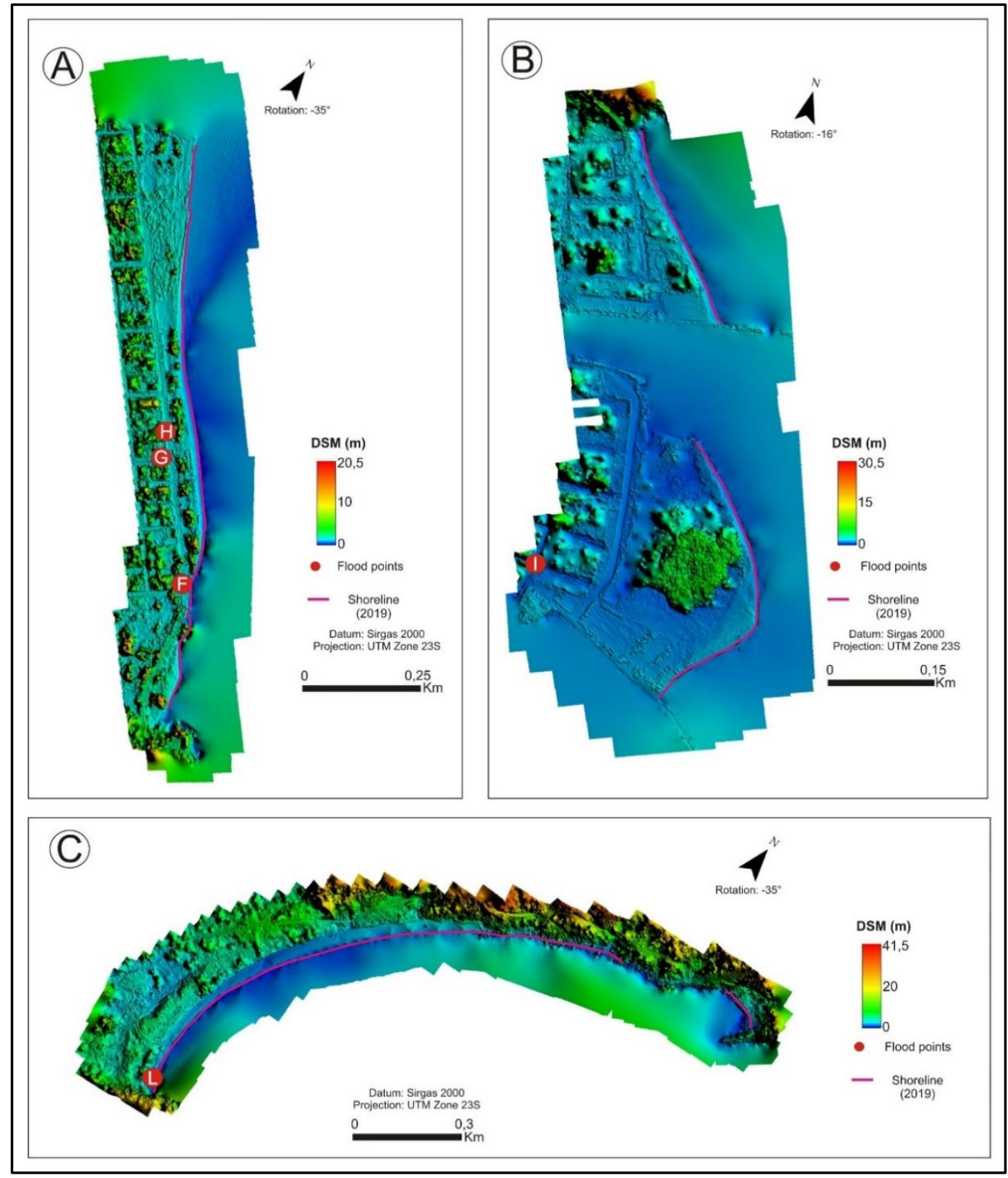

Figure 7. Digital surface model (DSM) and flood points. Caption: the flood points are represented by letters, which correspond to the images in Figure 4. Self elaborated.

In the central area of Paraty, during the same events, the flooded altitude was $0.8 \mathrm{~m}$ in relation to mean sea level (Figure 4I), flooding an area of approximately 26,742 $\mathrm{m}^{2}$ (Figure $8 \mathrm{~B}$ ). The area south of the Perequê-Açu river is the most susceptible to flooding. Areas close to the mouth, inside estuaries and at low altitudes areas not protected by frontal dunes, are generally susceptible to flooding (Vianna et al., 2020). Even though they are sheltered areas with low energy waves (not exceeding $1 \mathrm{~m}$ in height), during extreme events, the water level covers the entire 
beach and invades sidewalks and streets parallel to the beach (Figure 4F to $\mathrm{K}$; Figure $8 \mathrm{~A}$ and $\mathrm{B}$ ). This scenario is even more worrying when considering the increase in the number and intensity of the most intense storms around the world in recent decades (Webster et al., 2005; Holland and Bruyère, 2014) and the increase in mean sea level, which, in the worst-case scenario, could reach a maximum of $0.82 \mathrm{~m}$ by 2100 (IPCC, 2014). In addition to being low and narrow areas, sheltered coast and low hydrodynamic energy generally have a denser urban occupation (Nordstrom, 1989; Vila-Concejo et al., 2020), which can generate even greater damage during flood events.

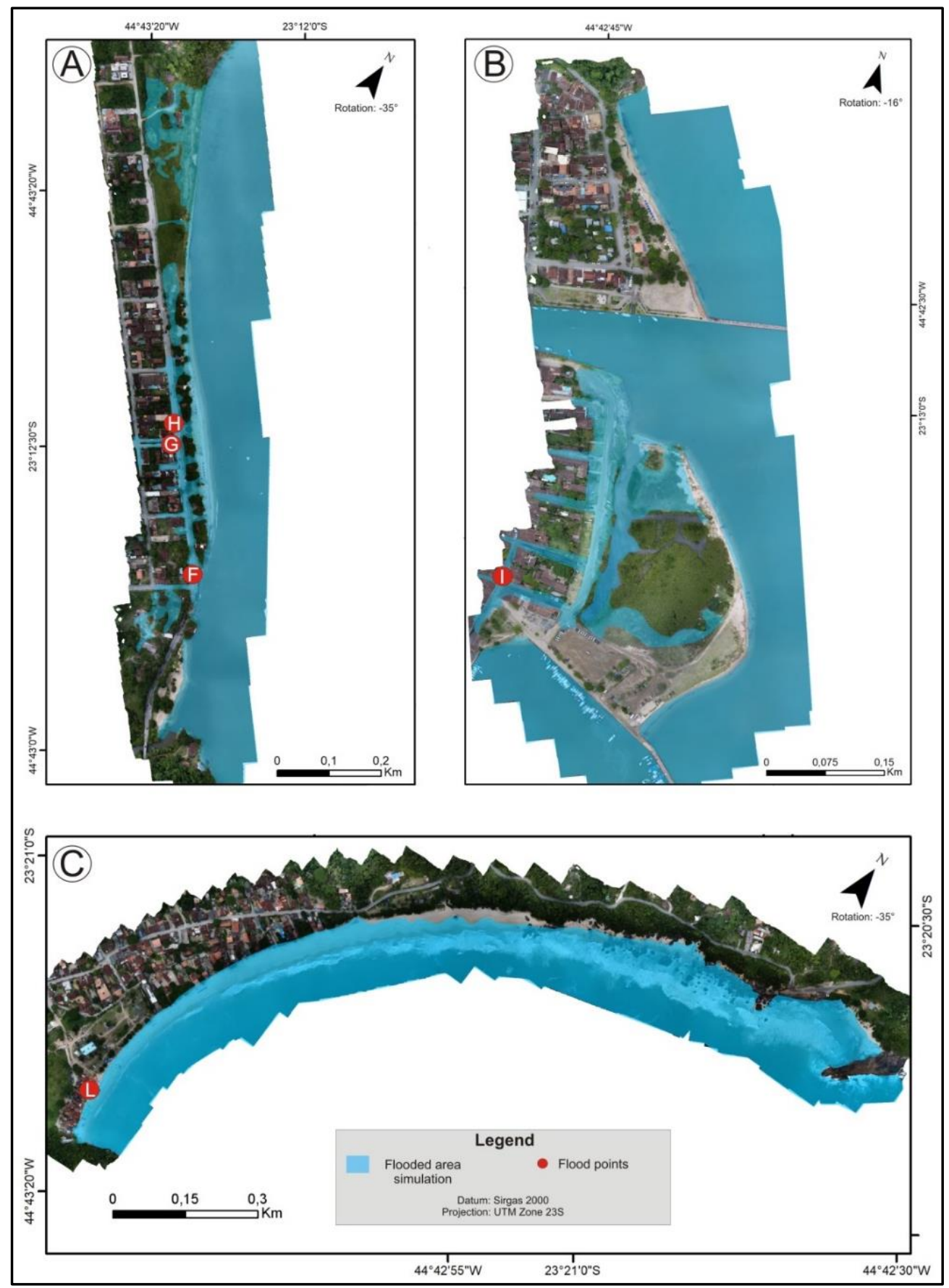

Figure 8. Flooded area simulation during extreme events in 2016. A: Jabaquara Beach, maximum flooded altitude of $1.3 \mathrm{~m}$; B: Centro, maximum flooded altitude of $0.8 \mathrm{~m}$; C: Trinidad, maximum flooded altitude of $2.4 \mathrm{~m}$. Caption: the flood points are represented by letters, which correspond to the images in Figure 4. Self elaborated. 
The Trindade coast proved to be less susceptible to flooding, compared to the other areas, due to the higher altitude of the beach and nearby areas (Figure 7C). A momentary rise in mean sea level, occurring during storm events, would have to be greater than $2 \mathrm{~m}$ (Figure $8 \mathrm{C}$ and Figure $4 \mathrm{~L}$ ) to cover the beach and reach buildings located in the area of the back beach, as occurred in August 2016 (Figure 4D, E, and L). However, Trindade is located on the oceanic part of the coast of Paraty and, consequently, is subject to rapid changes in sea conditions, when storm waves can reach heights of over $3 \mathrm{~m}$ in the surf and eventually reach buildings located within the back beach. In 2016, around $49,610 \mathrm{~m}^{2}$ of area were flooded (Figure 8C) during the storm, causing damage to the entire beach arc. In Trindade, the area most impacted by storm and flood events was Ranchos Beach (Figure 4D, E, and L), where there is also the highest density of buildings, many of them located inside the beach area, such as kiosks and restaurants. Many of these buildings were destroyed or damaged during the extreme events that took place in 2016 (Figure 4D, E, and L). The greatest damage caused by coastal flooding generally occurs in areas with the highest concentration of buildings, as observed by Vianna et al. (2020) and Maia et al. (2016) on the Rio Grande do Sul coast and by Höffken, et al. (2020) on the German coast. Among the areas studied in Paraty, Jabaquara Beach, the central area of Paraty, and Ranchos Beach (Trindade) were considered the most vulnerable, due to their greater susceptibility to flooding and the high concentration of urban structures at risk of damage.

\section{FINAL CONSIDERATIONS}

The beaches of Jabaquara and the Central Area of Paraty, which are sheltered regions along the studied coast, presented erosive behavior with retreat of the shoreline over the 14 years analyzed. The central sector of the Jabaquara Beach arc was the only area that showed accretion behavior with an advance of the shoreline. The erosion process in the central areas of Paraty (Jabaquara and Centro) may be associated with certain factors, such as susceptibility to the action of storm waves; low exchange of sediments with adjacent beaches due to low wave energy; and, mainly, the interventions carried out in this region, which may have altered the hydrodynamics and the contribution of sediments to the beaches. The beaches located in Trindade also showed erosive behavior, with retreat of the shoreline during the analyzed period, except for Ranchos Beach, which showed stable behavior over the same period, albeit with high susceptibility to erosion. In Trindade, the sea conditions change rapidly, with a predominance of the direct incidence of high energy waves during storm events, which can reach more than $3 \mathrm{~m}$ in height in the breaker zone. During such storm events, waves hit buildings located near the sandy beach and cause flooding.

Jabaquara Beach and the central Area of Paraty (Centro) were considered the most susceptible to flooding, mainly due to the low altitude of the coastal plain. A momentary rise of a few centimeters in mean sea level during storm events associated with the spring tide tends to cause frequent flooding in these areas. Among the areas studied in Paraty, Jabaquara Beach, the central area of Paraty, and Ranchos Beach (Trindade) were considered the most vulnerable, due to their greater susceptibility to flooding and the greater density of buildings near and within the limits of the beach, such as kiosks, restaurants, and residences, which could be directly affected, causing widespread damage, with a strong impact on economic activities such as tourism.

Coastal erosion and flooding events may become more frequent, due to the likely scenario of an increase in mean sea level, along with ongoing climate change. Therefore, studies on the management of coastal areas are increasingly necessary. Studies of this nature on the coast of Paraty are scarce, although they are fundamental for the knowledge of the several variables related to the dynamics and behavior of the shoreline, which can help in decision-making and measures related to local coastal management.

\section{ACKNOWLEDGEMENTS}

We would like to thank the Coordenação de Aperfeiçoamento de Pessoal de Nível Superior (Coordination for the Improvement of Higher Education Personnel) (CAPES) for the doctoral scholarship granted to Ana Beatriz Pinheiro and the Postgraduate Program in Ocean and Earth Dynamics at UFF and the Coastal Studies Group (GECOST) at FFP-UERJ for all the support given throughout this work.

\section{REFERENCES}

ADGER, W.N.; BROOKS, N.; KELLY, M.; BENTHAM, G.; AGNEW, M.; ERIKSEN, S. New indicators of vulnerability and adaptive capacity. 
Tyndall Centre for Climate Change Research (Technical Report 7: Final Project Report), 2004.

ALBUQUERQUE, M. G., ALVEZ, D. C. L., ESPINOZA, J. M. A., OLIVEIRA, U. R., SIMÕES, R. S. "Determining Shoreline Response to Meteooceanographic Events Using Remote Sensing and Unmanned Aerial Vehicle (UAV): Case Study in Southern Brazil". Journal of Coastal Research. Vol 85, 2018, p. 766-770

BENCHIMOL, M. F. Gestão de unidades de conservação marinhas: um estudo de caso da área de proteção ambiental da Baía de Paraty RJ. 2007. MSc Dissertation. Universidade Federal do Rio de Janeiro, Brasil, 2007.

BIRD, E. C. F. Coastal Geomorphology: An Introduction. 2. ed. Other Wiley Editorial Offices, Inglaterra, 2008.

BOAK, E.H. \& TURNER, I.L. "Shoreline definition and detection: a review". Journal of Coastal Research. Vol 21, n 4, 2005, p. 688-703

BOER, W.; MAO, Y.; HAGENAARS, G.; VRIES, S.; SLINGER, J.; VELLINGA, T. "Mapping the Sandy Beach Evolution Around Seaports at the Scale of the African Continent". Journal of Marine Science and Engineering. Vol 7, 2019, p. 151.

BUSH, D.M.; NEAL, W.J.; YOUNG, R.S. \& PILKEY, O.H. "Utilization of geoindicators for rapid assessment of coastal - hazard risk and mitigation". Ocean and Coastal Management. Vol 42, 1999, p. 647-670,

CARTER, R. W. G. Coastal Environments: An Introduction to the Physical, Ecological and Cultural Systems of Coastlines. 1. ed. Academic Press, London, 1988.

COOPER, J. A. G.; MASSELINK, G.; COCO, G.; SHOR, A. D.; CASTELLE, B.; ROGERS, K.; ANTHONY, E.; GREEN, A. N.; KELLEY, J. T.; PILKEY, O. H.; JACKSON, D. W. T. "Sandy beaches can survive sea-level rise". Nature Climate Change. Vol 10, 2020, p. 993-995.

COOK, K. L. "Na evaluation of the effectiveness of low-cost UAVs and structure from motion for geomorphic change detection". Geomorphology. Vol 278, 2017, p. 195-208.

CARVALHO, C; ANJOS, R.M., VEIGA R., MACARIO K. "Application of radiometric analysis in the study of provenance and transport processes of Brazilian coastal sediments". Journal of Environmental Radioactivity. Vol 1, 2011, p. 1-13.

CASTILLO, G. B.; Llopis, I. A.; Murillo, L. F. S; Calderón, J. F. V. "Critical beaches due to coastal erosion in the Caribbean south of Costa Rica, during the period 2005-2016". Revista Geográfica da América Central, vol 64, 2020, p. 123-149.

CASTILLO, G. B.; MURILLO, L. F. S. "Cambios en la línea de costa en el Caribe Sur de Costa Rica durante el periodo 2005-2016". Revista de Ciencias Ambientales (Tropical Journal of Environmental Sciences), vol 55, n 2, 2021, p. 111-140.

CASTRO, L. Q.; ROCHA T. B.; VIEIRA, R. "Mapeamento da linha de costa e avaliação da vulnerabilidade e susceptibilidade à erosão costeira entre a foz do rio São João e a foz do rio Una - Cabo Frio/RJ". Arquivos de Ciências do Mar, vol 53, 2021, p. 7-24.

CPTEC/INPE. Centro de Previsão de Tempo e Estudos Climáticos, 2016 [consulta: 10.11.2016]. Disponivel em: https://www.cptec.inpe.br

DAVIS JR, R. A., Fitzgerald, D. M. Beaches and Coasts.1. ed. Blackwell Publishing, 2004.

DHN, Diretoria de Hidrografia e Navegação da Marinha do Brasil, 1980. Folha de Bordo, FB1500-001/79.

DIAS, G. T. M.; Kjerfve, B. Barrier and Beach Ridge Systems of the Rio de Janeiro Coast. In: DILLENBURG, S. R., HESP, P. A. Geology and Geomorphology of Holocene Coastal Barriers of Brazil. Berlin: Springer-Verlag, 2009, p. 225-252.

DO, A. T. K.; VRIES, S.; STIVE, M. J. F. "The Estimation and Evaluation of Shoreline Locations, Shoreline-Change Rates, and Coastal Volume Changes Derived from Landsat Images". Journal of Coastal Research. Vol 35, 2019, p. 56-71.

GODOI, V. A., CALADO, L., WATANABE, B. W., YAGINUMA, L., PEREIRA, M. B. "Evento extremo de ondas na baía da llha Grande: um estudo de caso!. Boletim do Observatório Ambiental Alberto Ribeiro Lamego. Vol 5, 2011, p. 28-44.

GONÇALVES, J.A., BASTOS, L., PEREZ, B., MAGALHÃES, A. "Monitoring of beaches and sand dunes using digital aerial photography with direct georeferencing". International Archives of the Photogrammetry, Remote Sensing, 2010, p. 228-232.

GONÇALVES, J.A.; HENRIQUES, R. "UAV photogrammetric for topographic monitoring of coastal areas. ISPRS" Journal of Photogrammetry and Remote Sensing., vol 104, 2015, p. 101-111. 
HOLLAND, G., BRUYÈRE, C.L. Recent intense hurricane response to global climate change. Climate Dynamics. 2014, 42, pp. 617-627.

HÖFFKEN, J.; VAFEIDIS, A. T.; MACPHERSON, L. R.; DANGENDORF, S. "Effects of the Temporal Variability of Storm Surges on Coastal Flooding. Frontiers". Marine Science. Vol 7, 2020,, p. 1-14.

IPCC, 2014: Climate Change 2014: Synthesis Report. Contribution of Working Groups I, II and III to the Fifth Assessment Report of the Intergovernmental Panel on Climate Change [Core Writing Team, R.K. Pachauri and L.A. Meyer (eds.)]. IPCC, Geneva, Switzerland, 2014.

JACKSON, N.L., NORDSTROM, K.F., ELIOT, I. \& MASSELINK, G. "Low energy sandy beaches in marine and estuarine environments: a review". Geomorphology. Vol 48, 2002, p. 147-162.

KIM, I. H., LEE, H. S., KIM, J. H., YOON, J. S., HUR, D. S. "Shoreline change due to construction of the artificial headland with submerged breakwaters". Journal of Coastal Research. Vol 72, 2014, p. 145-150.

KLEMAS, V. "Beach Profiling and LIDAR Bathymetry: An Overview with Case Studies". Journal of Coastal Research. Vol 27, n 6, 2011, p. 1019-1028.

KUDALE, M. D. "Impact of port development on the coastline and the need for protection". Indian Journal of Geo-Marine Sciences. Vol 39, 2010, p. 597-604.

KLEIN, R. J.T., NICHOLLS, R. J. "Assessment of coastal vulnerability to Climate Change". AMBIO A Journal of the Human Environment. Vol 28, n 2, 1999, p. 182-187.

LUIJENDIJK, A.; HAGENAARS, G.; RANASINGHE, R.; BAART, F.; DONCHYTS, G.; AARNINKHOF, S., "The State of the World's Beaches". Nature Scientific Reports., vol 8, 2018, p. 6641 .

MACEDO, R. J. A.; MANSO, V. A. V.; PEREIRA, N. S.; FRANÇA, L. G. "Transporte de Sedimentos e Variação da Linha de Costa em Curto Prazo na Praia de Maracaípe (PE), Brasil." Revista da Gestão Costeira Integrada, vol 12, n 3, 2012, p. 343-355.

MAHIQUES, M.M. Considerações sobre os sedimentos de superfície de fundo da Baía da llha Grande, Estado do Rio de Janeiro. 1987. 158 f. MSc Dissertation Universidade de São Paulo, São Paulo.

MAIA, N. Z.; CALLIARI, L. J.; NICOLODI, J. L. "Analytical model of sea level elevation during a storm: Support for coastal flood risk assessment associated with cyclone passage". Continental Shelf Research. Vol 124, 2016, p. 23-34.

MEDEIROS, M. F. Estudos da sequência sedimentar holocênica das baías da ribeira e parati (Baía llha Grande - RJ) através de métodos sísmicos e análise de testemunhos. MSc Dissertation. Universidade Federal Fluminense, Niterói, Brasil, 2006.

MITASOVA, H.; OVERTON, M. F.; RECALDE, J. J.; BERNSTEIN, D. J.; FREEMAN, C. W. "RasterBased Analysis of Coastal Terrain Dynamics from Multitemporal Lidar Data". Journal of Coastal Research. Vol 25, n 2, 2009, p. 507-514.

MOREIRA, T. F.; ALBUQUERQUE, M. G.; ESPINOZA, J. M. A. 3, PAULA, D. P.; ALVES D. C. L.; BARROS E. L.; BENDÔ, A. R. R. CONCEIÇÃO, T. F. "Estudo do comportamento da linha de costa na praia do Icaraí (Caucaia, Ceará), a partir dos métodos digital shoreline analysis system e do polígono de mudança". Revista Brasileira de Geografia Física. Vol $13 \mathrm{n}$ 07, 2020, p. 3395-3411.

MUEHE, D. O Litoral brasileiro e sua compartimentação. In: Cunha, S. B. \& Guerra, A. J. T. Geomorfologia do Brasil. 2 ed., Bertrand Brasil, Rio de Janeiro, 2001, pp. 273 -337.

Muehe, D., Lima. C. F., Lins De Barros, F. Erosão e progradação do litoral brasileiro. 1. ed., Ministério do Meio Ambiente, Brasília, 2006.

MUEHE, D.; LINS DE BARROS, F.; BULHÕES, E. M. R.; KLUMB-OLIVEIRA, L. PINTO. N.; SPERLE, M. Panorama da erosão costeira no Brasil. Ministério do Meio Ambiente, Brasília, 2018.

NORDSTROM, K. F. "Erosion control strategies for bay and estuarine beaches". Coastal Management. Vol 17, 1989, p. 25-35.

NOVAK L. P.; LAMOUR, M. R. "Avaliação do risco à erosão costeira em praias urbanizadas do Paraná". Revista Brasileira de Geomorfologia. Vol 22, 2021, p. 163-185.

OLIVEIRA, U.R.; SIMÕES, R.S. Geomorfologia da costa central e sul do Rio Grande do Sul a partir de fotografias oblíquas de Drone. Editora da FURG, 2018.

OLIVEIRA, U. R.; SIMÕES, R. S.; CALLIARI, L. J.; CAVALCANTI, B. G. "Erosão de dunas sob ação de um evento extremo de alta energia de ondas na costa central e sul do Rio Grande do Sul, Brasil". Revista Brasileira de Geomorfologia. Vol 20, 2019, p.137-158. 
OLIVEIRA, U. R.; SIMÕES, R. S.; PORTO, F. S.; CAMINHA, E. S.; CALLIARI, L. J.; ROMEU, M. A. R. "Análise da dinâmica praial após a deposição de lama em 2014 na praia do Cassino (RS, Brasil) utilizando aeronave remotamente pilotada". Revista Brasileira de Geomorfologia. Vol 21, n 3, 2020, p. 677-695,

OTVOS, E.G. Beach ridges - definitions and significance. Geomorphology, 2000, no.32, p. 83108.

PE'ERI, S.; LONG, B. "LIDAR Technology Applied in Coastal Studies and Management". Journal of Coastal Research. Vol 62, 2000, p. 15.

PINHEIRO, A. B.; SILVA, A. L. C. "Análise da sensibilidade ambiental do litoral de Paraty (Estado do Rio Janeiro, Brasil) a potenciais derramamentos de óleo". Revista Geográfica de América Central. Vol 66, 2021, p. 158-188.

PINHEIRO, A. B.; SILVA, A. L. C.; BAPTISTA NETO, J. A. "Dynamics and storm records on sheltered beaches: Paraty, southeast coast of Brazil". Journal of Sedimentary Environments. Springer Nature Switzerland, 2021, p. 1-17.

REMONDINO, F., BARAZZETTI, L., NEX, F., SCAIONI, M., SARAZZI, D. UAV photogrammetry for mapping and $3 \mathrm{D}$ modeling - current status and future perspectives. International Archives of the Photogrammetry, Remote Sensing and Spatial Information Sciences, 2011, p. 25-31.

REVELL, D. L.; KOMAR, P. D.; SALLENGER JR, A. H. An "Application of LIDAR to Analyses of EI Nino Erosion in the Netarts Littoral Cell, Oregon". Journal of Coastal Research. Vol 18, n 4, 2002, p. 792- 801.

SALGADO, C. M., PEIXOTO, M. N. O., MOURA, J. R. S. "Caracterização espaço temporal da chuva como subsídio à análise de episódios de enchentes no município de Angra dos Reis, RJ". Revista Geosul. Vol 22, 2007, p. 7-26.

SALLENGER JR, A. H.; KRABILL, W. B.; SWIFT, R. N.; BROCK, J. "Quantifying hurricane-induced coastal changes using topographic Lidar". Proceedings Coastal Dynamics. vol 1, 2001, p. 1007-1016.

SALLENGER JR, A. H.; KRABILL, W. B.; SWIFT, R. N.; BROCK, J.; LIST, J.; HANSEN, M.; HOLMANR, R. A.; MANIZADES, S.; SONNTAG, J.; MEREDITH, A.; MORGAN, K.; YUNKEL, J.K.; FREDERICK E. B.; STOCKDON, H. "Evaluation of Airborne Topographic Lidar for Quantifying Beach Changes". Journal of coastal Research. Vol 19, 2003, p. 125-133.
SANTOS, E. C.; BONETTI, J. "Análise da taxa de variação da linha de costa da Enseada de Tijucas (SC) em diferentes escalas temporais como indicadora de suscetibilidade costeira". Quaternary and Environmental Geosciences. vol 09, n 2, 2018, p. 19-25.

SCARELLI, F.M.; CANTELLI, L.; BARBOZA, E.G.; ROSA, M.L.C.C., AND GABBIANELLI, G. "Natural and Anthropogenic coastal system comparison using DSM from a low-cost UAV survey (Capão Novo, RS/Brazil)". Journal of Coastal Research. Vol 75, 2016, p. 1232-1236.

SILVA, A. L. C., GRALATO, J. C. A., BRUM, T. C. F., SILVESTRE, C. P., BAPTISTA, E. C. S., PINHEIRO, A. B., "Dinâmica de praia e susceptibilidade às ondas de tempestades no litoral da Ilha Grande (Angra dos Reis -RJ)". Journal of Human and Environment of Tropical Bays vol 1, 2020, p. 9-44.

SILVA, M. T; LOPES, D. N.; REBOUÇAS, I. S.; FREIRES, E. V.; NETO, C. A. S.; DUARTE, C. R.; SOUTO M. V. S. "Variação da linha de costa no litoral cearense (1984-2018)". Revista Brasileira de Geografia Física. Vol 12 n 7, 2019, p. 25512579.

SIMÕES R.S., OLIVEIRA U.R., ESPINOZA J.M.A., ALBUQUERQUE M.G., ALVES D.C.L. "Uso de Drone de pequeno porte para análise costeira: enfoque metodológico". Revista Brasileira de Geografia Física. Vol 12 n 2, 2019, pp. 622-640.

SIMÕES, R. S.; OLIVEIRA, U. R. "Monitoramento mensal da linha de costa no Balneário Mostardense-RS entre 2016/2017 utilizando dados de VANT". Quaternary and Environmental Geosciences. Vol 11 n 1, 2020, pp. 1-18.

SOUZA, C. R. G. A. "Erosão Costeira e os Desafios da Gestão Costeira no Brasil". Revista da Gestão Costeira Integrada. Vol 9, p. 2009, 1737.

SOUZA, C. R. G; LUNA, G. C. "Variação da linha de costa e balanço sedimentar de longo período em praias sob risco muito alto de erosão do município de Caraguatatuba (Litoral Norte de São Paulo, Brasil)". Revista da Gestão Costeira Integrada. Vol 10 n 2, 2010, p. 179-199.

STIVE, M.J.F; AARNINKHOF, S.G.J.; HAMM, L.; HANSON, H.; LARSON, M.; WIJNBERG, K.M.; NICHOLLS, R.J.; CAPOBIANCO, M. "Variability of shore and shoreline evolution. Coastal Engineering". Vol 47, 2002, p. 211- 235.

STOCKDONT, H. F.; SALLENGER JR, A. H.; LIST, J. H.; HOHNAN, R. A. "Estimation of 
Shoreline Position and Change using Airborne Topographic Lidar Data". Journal of Coastal Research. Vol 18 n 3, 2002, p. 502-513.

TONKIN T.N, MIDGLEY N.G., GRAHAM D.J., LABADZ J.C. "The potential of small unmanned aircraft systems and structure-from-motion for topographic surveys: A test of emerging integrated approaches at Cwm Idwal, North Wales". Geomorphology. Vol 226, 2014, p. 35-43.

TAK, W. J.; JUN, K.W.; KIM, S.D.; LEE, H. J. "Using Drone and LiDAR to Assess Coastal Erosion and Shoreline Change due to the Construction of Coastal Structures". Journal of Coastal Research. Vol 95, 2020, p. 674-678.

TAMURA, T. "Beach ridges and prograded beach deposits as palaeoenvironment records". EarthScience Reviews. Vol 114, 2012, pp. 279-297.

TSOUKALA, V. K., KATSARDI, V., HADJIBIROS, K., MOUTZOURIS, C. I. "Beach Erosion and Consequential Impacts Due to the Presence of Harbours in Sandy Beaches in Greece and Cyprus". Environ. Process. Vol 2, 2015, p. 55-71.

VIANNA, H. D.; CALLIARI, L. J. "Variabilidade do sistema praia-dunas frontais para o litoral norte do Rio Grande do Sul (Palmares do Sul a Torres, Brasil) com o auxílio do Light Detection and Ranging - Lidar". Pesquisas em Geociências. Vol 42, n 2, 2015, p. 141-158.

VIANNA, H. D.; CALLIARI, L. J.; VIANNA, S. D. "Inundação e erosão na costa norte do Rio Grande do Sul - Brasil. estudo de caso: a maré meteorológica de outubro de 2016". Revista Brasileira de Geomorfologia. Vol 21, n 4, 2020, p. 719-739.

VILA-CONCEJO, A, GALLOPB, S. L., Largier, J. L. "Sandy beaches in estuaries and bays. In: Jackson, D. W. T., Short, A. D. Sandy Beach Morphodynamics", Elsevier, Estados Unidos, 2020, p. 343-362.

VILLENA, H. H., PEREIRA, S. D., GERALDES, M. C., CHAVES, H. A. F., HERMS, F. W., FERREIRA, M. G., ALMEIDA E. R., BARROS, I. P., MAFIA, J. R. "Morfologia de fundo e cobertura sedimentar da Baía de Paraty". Revista Interações Homem-Meio nas Zonas Costeiras Brasil/Portugal. Vol 1, 2013, p. 263 -277.

VILES, H. "Technology and geomorphology: Are improvements in data collection techniques transforming geomorphic science". Geomorphology. Vol 270, 2016, p. 121-133.

VOUSDOUKAS, M. I.; MENTASCHI, L.; VOUKOUVALAS, E.; VERLAAN, M.; JEVREJEVA, S.; JACKSON L. P.; FEYEN, L. "Global probabilistic projections of extreme sea levels show intensification of coastal flood hazard". Nature Communications. Vol 9, 2018, p. 1-12.

WEBSTER, P. J., HOLLAND, G. J., CURRY, J. A., CHANG, H. R. "Changes in Tropical Cyclone Number, Duration, and Intensity in a Warming Environment". Science. Vol 309, 2005, p. 18441846. Doi.10.1126/science. 1116448 